Article

\title{
Practices of corporate social responsibility in the UAE banking sector: An assessment
}

\author{
Aarthi S.V ${ }^{1 *}$, Mrutuyanjaya Sahu² \\ $1 \mathrm{PhD}$ Research Scholar, Department of Humanities and Social Sciences, Birla Institute of Technology \& \\ Science, Pilani, Dubai Campus, UAE; p20190904@dubai.bits-pilani.ac.in \\ 2 Assistant Professor, Department of Humanities and Social Sciences, Birla Institute of Technology \& Science, \\ Pilani, Dubai Campus, UAE; m.sahu@dubai.bits-pilani.ac.in \\ * Correspondence: p20190904@dubai.bits-pilani.ac.in
}

Received: 16 February, 2021; Accepted: 14 June 2021; Published: 18 June 2021

\begin{abstract}
There is a conspicuous lack of research on Corporate Social Responsibility (CSR) practices undertaken in the United Arab Emirates, more so in the banking sector. This paper attempts to fill the gap by examining the government policies drawn up to support enterprises in their CSR efforts. The paper aims to examine the nature and practices of CSR undertaken by the banking sectors in the UAE. UAE's desire to go beyond being a tourist destination to an international business hub and financial market has resulted in their desire to set up CSR activities. In the UAE the banking sectors are the first to have adopted social responsibility and worked to advance it. Banks like Mashreq, ADCB, and Emirates NBD have actively involved themselves in CSR projects. For this study, ten UAE banks (Islamic and Non-Islamic banks) have been chosen based on purposive sampling to ensure the selected banks are currently or in the recent past involved themselves in CSR projects.
\end{abstract}

Keywords: Corporate social responsibility; banking sector; UAE; sustainability

JEL codes: M14; Q56; Q01

\section{Introduction}

In the era of liberalization and globalization, corporate social responsibility (CSR) has become a familiar concept whereby corporate sector companies consider the interests of society by taking responsibility for the impact of their activities. Understanding of the term CSR has evolved since the industrialization era (Ahuja, 2015). The last few decades have seen an increased awareness about the social responsibility of corporates the world over. The role of business in society is no longer just profitmaking at all costs. The social responsibility of corporates has become a subject of public debates forcing the board rooms of corporations around the world to take notice (Safwat, 2015). A few decades ago, CSR was synonymous with just philanthropy. Now, as people are getting increasingly conscious about the environment and demanding ethical business practices, it is expected that business organizations become concerned about their responsibilities towards their stakeholders, customers, and the society around them (Visser et al., 2008).

The concept of CSR aims to explore the role of businesses in society and maximize the positive societal outcomes of their activities (Sajadi Far, 2013). Scholars believe that corporates also gain from their CSR initiatives. In his 2014 research, Hopkins states that -there is a positive link between social and financial performance, specifically in terms of increased relevance of intangible assets such as reputation and knowledge networks (Hopkins,2014). Performing CSR is believed to improve brand recognition and brand reputation. Customer loyalty is indirectly affected by perceived CSR via the mediation of trust, identification, and satisfaction. (Martínez \& Bosque, 2013). Sustainable products and companies that follow sustainable practices also attract consumers (Business News Daily, 2019, Harvard Business Review, 2019). By adopting sustainable practices, the corporation can also reduce 
operational costs and convert waste into potential revenue streams (Sustainability Magazine, 2016, Maslennikova \& Foley, 2021). Many larger organizations have already integrated CSR into their strategic plans as an essential factor to have a sustainable and ethical work environment that attracts top talent and retains key employees. (Vinerean et al. 2013, Newswire.ca, 2010, Pyszka \& Gajda, 2015). CSR initiatives also lead to a stronger relationship with the communities around them and better stakeholder engagement. Many companies like Nestle and Xerox have ascertained that CSR is not just good ethics but also good business (Singh, Bawa, \& Sharma, 2016).

CSR was not considered important in developing countries until the recent world downturn, which has shaken business leaders to think about being socially responsible while doing business and making profits. However, in developed countries, CSR appears to push and monitor larger organizations to adopt socially responsible business policies and practices. It is not just restricted to accomplishing the economic and legal responsibilities, the two main factors in CSR identified by Carroll (1979). Over the last few years, CSR awareness is increasing in the Gulf states, particularly in the United Arab Emirates (UAE). In the UAE, CSR is in a flowering stage and facing daunting social and environmental challenges due to rapid economic development. Recently, the oil-rich state UAE has taken several policy measures to ensure firms support to achieve CSR goals (Okur, 2015). In the UAE, public and private organizations have also started to realize the importance of CSR as a vital part of attaining sustainability in a highly competitive business organization. Many UAE private sector companies have expanded beyond their essential economic functions and considered social and environmental aspects through CSR for their sustainability and development. One of the primary motivators for CSR in the UAE is the Dubai Chamber of Commerce and CSR center; namely, the Centre for Responsible Business (CRB), and several hundred organizations in the UAE adopt the practices from this center (Dubai Chamber, 2012).

This paper aims to examine the practices of CSR undertaken by the banking sector in the UAE. The paper is structured in the following manner. In the first section, the literature on CSR is reviewed. Second, the theoretical perspectives and drivers of CSR are highlighted. Third, the paper discusses the CSR practices in the banking sector across the world. The fourth section highlights CSR policy implementation in the UAE. The fifth section is devoted to the research objectives and methodology used in this study. The sixth section elucidates the findings of this study. Finally, the paper summarizes the findings.

\section{Corporate Social Responsibility: Conceptualization}

Corporations worldwide are struggling with a significant challenge, which is to meet the needs of the present generation without jeopardizing the ability of the next generations to meet their own needs (Devi, 2014). CSR (an outcome of the free-market ideology credited for the turbulent events in the finance, energy, and food market that have placed us in this position); has gained unprecedented attention in the political-economical dialogue. There is no universal definition of CSR; each definition currently available underpins the impact that businesses have on society at large and their societal expectations. Inconsistencies and debates regarding the proper definition of CSR have hampered scientific progress in understanding the antecedents and consequences of this activity. To conduct a definitional analysis of CSR, one must start at the first mention of CSR in literature. The argument that corporates must take social responsibility was introduced in 1938 by Chester Barnard in his publication, 'The Functions of the Executive' (Iatridis, 2011). The idea then took shape during the next four decades.

The academic literature provides various definitions of corporate social responsiveness. It is argued that business and society are interlinked: society has an absolute belief regarding business, and therefore companies have responsibilities towards the development of society. CSR can be defined as the "economic, legal, ethical, and discretionary expectations that society has of organizations at a given point in time" (Ghulliani, 2013). Naylor (1999) defined it as "the obligation of managers to choose and act in ways that benefit both the interests of the organization and those of society as a whole." The United Nations Industrial Development Organization defines 'CSR as a management concept in which 
a company achieves a balance of economic, environmental, and social imperatives (triple-bottom approach), while also addresses the expectations of shareholders and stakeholders' (UNIDO, 2020). Similarly, the European Union states that CSR is meant to achieve the triple bottom line- profits, protecting the environment, and fighting for social justice (Neelmani et al., 2015). The European Commission (2011) defines CSR as "the responsibility of enterprises for their impacts on society" (Masoud, 2017). Mc Williams and Siegel take a more ambiguous approach to CSR, defining it as actions that further some social good beyond the business interest of the firm (McWilliams, Siegel, 2001).

One of the most accepted definitions for CSR in both the academic world and the corporate sector was developed by Archie. B. Carroll. Carroll's four-part definition of CSR was initially stated as follows: "Corporate social responsibility encompasses the economic, legal, ethical, and discretionary (philanthropic) expectations that society has of organizations at a given point in time" (Carroll 1979, 1991). This set of four responsibilities creates an infrastructure that helps to delineate in some detail and to frame or characterize the nature of businesses' responsibilities to the society of which it is a part (Carroll, 2016). In 1991 Carroll organized the pyramid (Figure 1), which embodied the four different responsibilities of a business- economic, legal, ethical, and philanthropic - which, while not mutually exclusive, describes the relations between them (Masoud, 2017).

Figure 1. Carroll's pyramid of responsibilities

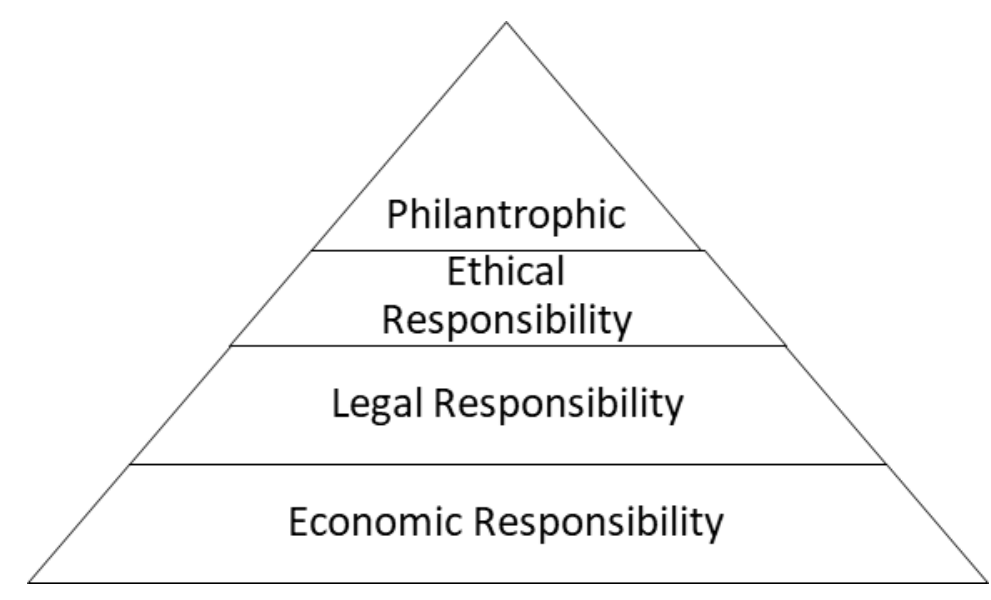

Economic responsibility: The first responsibility of any business is to function efficiently as an economic unit and continue to stay in business. Companies have a responsibility towards shareholders who expect a return on their investments; employees who need a fair paying job in a safe working environment; and customers who demand good quality products at an appropriate price (Habisch et al. 2005). Carroll states that the economic responsibilities are primary, and all subsequent responsibilities are based on this first layer of CSR (Holzinger et al., 2010).

Legal responsibility: Corporations are responsible for abiding by the law and its provisions (Habisch et al., 2005). The company must ensure that all operations are legal in the place of operation (in companies that operate in multiple countries). Carroll suggests that the satisfaction of legal responsibilities is required of all corporations seeking to be socially responsible (Holzinger et al., 2010). Any subsidiaries, contractors, and vendors must also be held to this standard.

Ethical responsibility: This responsibility obligates corporations to do what is right, just, and fair, even when they are not obliged to do so by the existing legal framework (Habisch et al. 2005). Carroll argues that ethical responsibilities consist of what is generally expected by society over and above economic and legal expectations (Holzinger et al., 2010).

Philanthropic responsibility: The fourth level of CSR is philanthropic responsibility. This aspect of CSR addresses charitable donations. CSR was considered synonymous with philanthropy until the post-World War II industrial revolution, it has since evolved to include more than that. (Habisch et al. 2005). Philanthropic activities are only a part of CSR, which otherwise constitutes a broader set of 
activities entailing strategic business benefits. Its mission is to provide innovative solutions for social and environmental challenges.

\section{Theoretical Perspectives of CSR}

This section discussed the significant theories on CSR and how they are connected to CSR in the UAE. During the research, we found stakeholder theory, social contract theory, and business ethics theory explain certain aspects of the drivers and status of CSR in the UAE.

\subsection{Stakeholder Theory}

The stakeholder theory has become a standard frame of reference for CSR. It is seen as a direct alternative and challenge to the shareholder value theory (Rahul, 2012). The theory interprets the relationship between the organization and its stakeholders. Much like shareholders invest their money in enterprises, employees invest their time and intellectual capital, customers support their trust and repeated business, and communities provide infrastructure and education for future employees (Graves et al., 2001). Hence, business organizations must play an active role in the society in which they operate. (Omran \& Ramdhony, 2015). In this perspective, the organization is not viewed as a mechanism that drives the maximization of shareholders' wealth but as one that meets all stakeholders' expectations (Lawrence \& Fernando, 2014). In the Gulf region, where the state and religion are closely tied. Religious believes and practices make their way into policies and regulations. For example, Islamic business organizations are required to deal justly with their stakeholders, including employees, clients, and all groups of stakeholders within the community in which they operate (Rahman \& Bukair, 2013). Also, Rettab and Ben Brik, in their 2008 study, identified six stakeholderscustomers, employees, investors, environmental supporters, experts, suppliers, and community members as a strong influence on companies in Dubai to adopt CSR. They (Noeiaghaei, 2009).

\subsection{Social Contract Theory}

Research states that social contract theory is appropriate for developed/emerged economies, as CSR disclosure exists according to Donaldson in 1982 due to an implicit social contract between business and society. According to this approach, firms are responsible to society, of which they are an integral part (Omran \& Ramdhony, 2015). The Commission of the European Communities $(2001,2002)$ and the Financial Times Top 100 Index also define CSR as corporations being held accountable by explicit or inferred social contract with internal and external stakeholders, obeying the laws and regulations of the government, and operating in an ethical manner which exceeds statutory requirements (Tariq et al. 2012). Similarly, in the Gulf region, where Islamic beliefs were built into policies and regulations, businesses are forbidden from performing any action involving exploitation or leading to unfairness or damage to society and the environment (Rahman \& Bukair, 2013).

\subsection{Business Ethics Theory}

The business ethics theory deals with the rights and wrongs of business (Abdullah \& Valentine, 2009). It covers an extensive scope of social obligations and their moral ethics and duties towards communities and societies. It defines CSR in three varied but interrelated ethical grounds.

Companies should accept the emerging social responsiveness and social expectations to particular social problems. Organizations should possess eternal or intrinsic ethical values, universal principles like social justice, fairness, and human rights. Corporate citizenship is that corporations should be a better citizens in society and contribute to social wellbeing. (N. K. Gupta \& Kasana, 2017). Connecting this theory to the UAE context; research shows that Islamic banks have the principle of sharing loss and profits; therefore, their financial statements have huge debt write-offs equivalent to losses (Singh \& Kukunuru, 2017). 
Figure 2.Business Ethics Theory
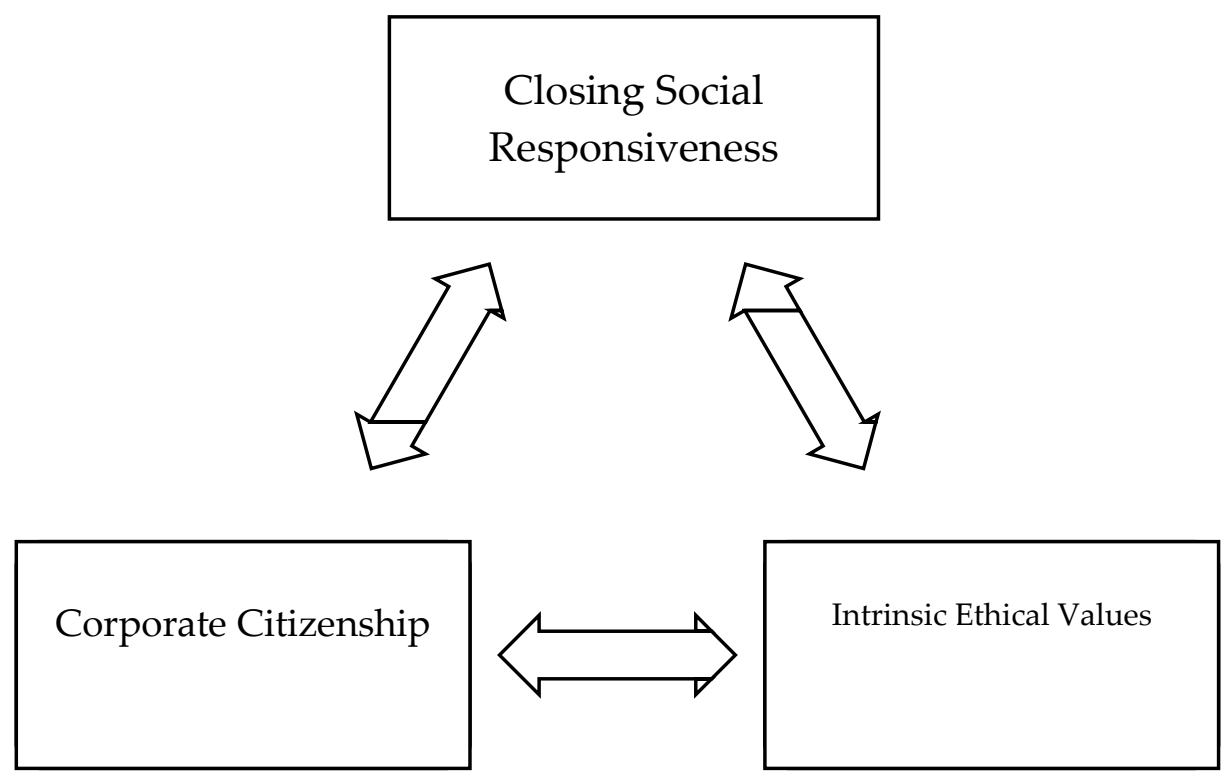

Source: N. K. Gupta \& Kasana, 2017

\section{Drivers of CSR}

CSR has evolved continually over the years; most of these transitions have been made due to the constant changes in the factors that drive CSR. CSR began as philanthropic projects undertaken by business owners on their own accord owing to their personal believes. International incidents like the Bhopal gas tragedy in India (1984), the nuclear reactor disaster at Chernobyl (Russia in 1986), and the Exxon oil spill of US costs (1989) changed the public perspective of industries (Toal \& Broomes, 2021). The failure of corporate sectors played a significant role in CSR development in the 1980s and 1990s. During these decades, the two main drivers, increasing concern about the environmental impacts of business practices and other 'social issues' (Noeiaghaei, 2009). Visser suggests that "socio-economic priorities, cultural tradition, political reform, governance gaps, and crisis response" have been added to the list and are among the essential driver of CSR in the global context (Masoud, 2017). The factors that drive CSR are not always a push from an external entity. Porter \& Kramer (2006) argue that "strategic CSR involves both inside-out and outside-in dimensions working in tandem" (Babiak \& Wolfe, 2009). Presently several internal and external drivers drive CSR. While "cultural traditions, government initiatives, socio-economic priorities, and market-driven priorities are external factors, investment imitative and stakeholder's initiative are internal factors" (Pinnington, 2013). Surveys conducted by David Vogel in 2005 and Ipos MORI (in the UK) assert the emergence of a trend of ethical consumerism wherein consumers view favorably, a prominent driving factor of CSR (Pal, 2016). Muller and Kolk (2009) put forward those internal factors such as 'managerial motivations', primarily driven by morality, which is a significant factor in an organization's inborn willingness to engage in social initiatives (Franzén et al., 2010). However, it is not always the case. In several organizations, the factors for CSR do not always come from top to down. At times, its employee initiative drive can also flow from middle to top management (Hallbäck, 2011).

In his research on CSR drivers, Visser adds international standardization and supply chain to external factors that drive CSR and crisis response to the internal factors. (Visser, 2008). The reputation of the organization and brand image are other internal factors (Hallbäck, 2011). In the case of MultiNational Corporations (MNCs), local circumstances play a significant component in how corporations choose to execute their CSR in different countries. CSR in each country is tailored to the social problems in a specific country and the relationship between MNC and the local government (Cramer, 2006). As 
discussed in the introduction section of this paper, the Islamic belief system which encourages philanthropy (Rahman \& Bukair, 2013), which is highly prevalent in the country, served as drivers for CSR in the UAE. It promotes the government to implement CSR policy and take protective measures to reduce environmental destruction of a fast-developing landscape and the desire for the UAE to be an important player in the region.

\section{CSR Practices in the Banking Sectors Around the World}

In recent times, competition in the banking sector is of a "non-price" nature; due to similar offerings made by many banks in a country. Therefore, banks must develop their brand image by creating a positive image (A. N. Kostyuk et al., n.d) (Islam \& Hamid, 2014). Several banks worldwide have adopted CSR as their means to a positive brand image. Financial institutions like banks are also involved in developmental funding projects for nation-building and improving their community. Hence, they must be socially responsible. Extensive study has been undertaken by academicians worldwide on CSR in the banking sector in developed and emerging economies.

Banks in the United States of America are oriented towards community interests and use philanthropy as the primary mode of CSR implementation. Most of the banks are involved in CSR due to the information transparency in this sector forcing the hand of the banks to be more socially responsible. The American banker's association has encouraged this by awarding the banks for their CSR efforts (A. N. Kostyuk et al., n.d). In the United Kingdom, it is the fierce competition among banks and government intervention, which encouraged banks to get involved in CSR. CSR management and reporting by the financial sector in the country is regulated by the FORCE guideline published (by the UK government, British Bankers Association, Association of British Insurers) in 2002 (A. N. Kostyuk et al., n.d). Since 2008 the Bangladesh banking sector has seen a steep increase in CSR spending which has gone up by over $1250 \%$ by the year 2012 (Islam \& Hamid, 2014). Several banks have adopted CSR projects; however, academics report a lack of transparency in CSR reporting in the country's banking sector. They attribute this to the absence of government guidelines or regulations for CSR in Bangladesh (Akter et al., 2018). Bangladesh, being a developing economy, the nature of CSR projects undertaken there are targeted at poverty alleviation, healthcare, women empowerment, youth development, etc. (Rahman et al., 2013). In Pakistan, $71.1 \%$ of commercial banks had begun publishing CSR reports by 2018, a significant increase from $56.4 \%$ a decade earlier (2008). Research attributes this to several factors like the intense competition within the banking sector, forcing banks to adopt CSR as a marketing tool and customer expectation (Khan \& Szegedi, 2020). CSR is ingrained in the business philosophy of Japan; this changed during the Occupation era in the country's history. Corporations have now adopted strategic CSR. Banks in the country focus on customer care, employee relations, supplier relations, and business success (A. N. Kostyuk et al., n.d). A study on the European banking sector shows that two-thirds (of the banks studied) of the banking sector shows commitment towards CSR. However, the lack of rigid regulations and guidelines has resulted in uncoordinated efforts towards reaching the UN's SDGs by the banking sector in Europe (Gallego-Sosa et al., 2021).

Over the past decade, CSR practices in the UAE banking sector have caught the attention of academics and researchers. Al- Tamimi, who studied the CSR practices of UAE banks, found the level of awareness about CSR among the management of UAE banks to be high. According to the study, most banks' preferred mode of performing CSR was to contribute towards or sponsor community activities (Al-Tamimi, 2013). Another study that researches the role of public policy in encouraging CSR in the UAE shows that; a policy that helps with strategy building will better serve businesses in the UAE to take a step towards CSR or fine-tune their existing strategy (Almatrooshi et al., 2018). However, the banking sector, which is the primary sector in CSR participation in the UAE, does not emphasize public policy support for CSR (Al-Tamimi, 2013). The sector which is active in undertaking CSR projects is not so when it comes to sharing communication about said activities. About $70 \%$ of the domestic banks in the UAE provide information about their CSR activities (Georgiadou \& Nickerson, 2020). Although the information provided is not comprehensive, some 
communications about their CSR initiatives are shared through official websites; in most cases, it is a single page of general information that does not go into the projects' details.

\section{Understanding CSR in the UAE}

While CSR is a well-established concept in the western world and developing countries in the east, UAE has shown the most progress in adopting CSR in the region (Al-Jenaibi, 2017). There are several drivers to the country's progress in CSR. The county's growing desire to become a first-class tourist, financial, and real estate center has been instrumental in compelling businesses to take note of the global corporate agenda to raise local practices to meet internationally accepted and expected standards (Noeiaghaei, 2009). According to Ararat (2006), some high-standard firms in the UAE have policies related to employee safety. Few companies do more by tackling issues like eliminating discrimination, establishing community and consumer policies, encouraging a healthy work-life balance for employees, and espousing practices that benefit environmental sustainability (Al-Jenaibi, 2017). Secondly, the UAE is a rapidly growing country- in the past decades, the country has faced rapid urbanization and population boom, leading to environmental impact (Okur, 2015). The government has since focused on safeguarding the natural resources of the country. The public and private sectors have been instructed to maintain strict compliance with business ethics and environmental regulations (Sajadi Far, 2013; Al-Jenaibi, 2017). Though CSR is a relatively new concept to the region, philanthropy and social work are not. Hence, the Islamic tradition of "Zakat" (giving) has been part of the culture for centuries and has for long been followed by local businesses (Okur, 2015; Sajadi Far, 2013). While zakat is voluntary in UAE (unlike other Muslim counties like Malaysia, Libya, Sudan, Pakistan, Saudi Arab who mandate it by Law), philanthropy is the most common form of social work performed by Emirati businesses (Okur, 2015). Even though 'Zakat' is very different from CSR in that its goal is a spiritual one, it is similar in that, like CSR, it is ultimately intended to ameliorate the lives of the larger community (Goby \& Nickerson, 2011).

Governments worldwide employ CSR as an instrument to encourage, rather than force, corporations to interact with sustainability goals (Steurer, 2013 as cited in Almatrooshi et al., 2018). For example, in the United Kingdom, there is a Minister for Small Business, Consumers, and Corporate Responsibility (Noeiaghaei, 2009). France has a law called Grenelle II, which legally obliges every listed company to integrate sustainability and CSR reporting like many European countries. South Africa and China use the CSR index in selected stock exchanges to rank companies based on CSR compliance (Kuriakose, 2017). In India, the New Companies ACT 2013 mandates a CSR spending of 2\% of the annual profit (India CSR Network, 2011).

Similarly, the UAE in 2018 passed a resolution in the cabinet to set up a governing body to draw up the framework for CSR and regulate CSR initiatives by businesses in the country. The mission of the CSR law is to encourage the business sector to actively engage in socially responsible practices that lead to a positive economic, social, and environmental impact in line with the UAE's priorities and sustainable development goals. The main objective of CSR is the development of social responsibility frameworks to regulate and reinforce social responsibility. In addition to CSR law, the UAE CSR Fund was set up the following year (csruae. ae, 2020). UAE has also adopted affirmative policy measures known as Emiratization to boost national employment (Goby \& Nickerson, 2011). In the banking sector, in which the Central Bank of UAE has mandated Emiratization, 26\% of the employees are natives (Al Rifai, 2019). The UAE CSR Fund aims to create awareness about social responsibility, assist firms in drawing up a framework for their CSR, and encouraged them to donates. The CSR UAE Fund handles governance of CSR activity undertaken by the public and private sectors. Another option provided to enterprises that cannot perform their CSR is to work with the CSR UAE Fund to direct contributions to national priority initiatives. The Fund will also work towards fulfilling the county's Sustainable Development Goals (SDGs) (csruae. ae,2020; Smith et al., 2018). The CSR UAE Fund has created a reward system for corporations and business entities like the CSR Labels, CSR membership badge, and the CSR passport. The CSR labels are awarded to enterprises involved in CSR projects and successfully fulfill the requirements for the three levels of CSR labels to publish a yearly report of their 
CSR report. CSR membership badge is given to honor companies contributing to the projects list on the CSR Smart Platform. CSR passport is a reward given to the top 5 private-sector entities for their CSR excellence. Companies can apply if they support a unique, innovative 3 -year CSR project addressing UAE's national priorities and applying strong CSR-related governance practices. They are rewarded with the CSR passport, which affords them several exclusive privileges and opportunities to companies (CSR, UAE, 2020).

Figure 3: Function of CSR UAE Fund

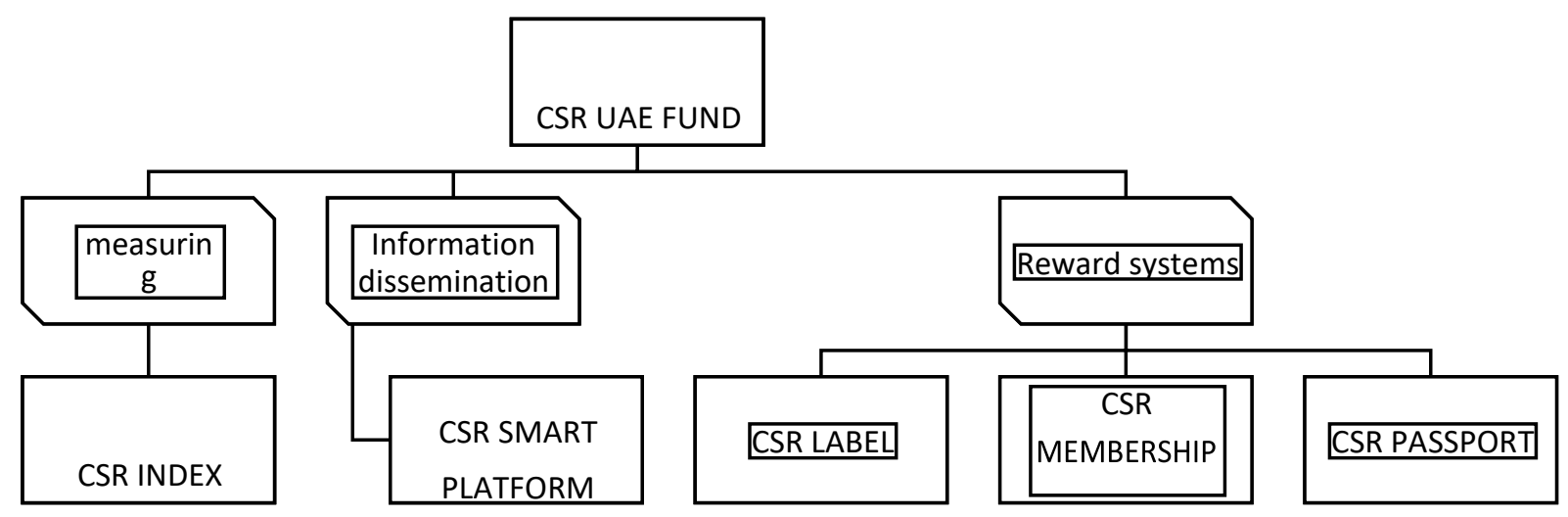

Source: Computed by the Author from different sources.

The CSR INDEX measures and ranks the CSR and sustainability practices of organizations in the UAE. The Index has 32 indicators and 20 sub-indicators correspondings with international standards. It aims to ensure the continual improvement of CSR practices of organizations by identifying gaps and limitations that can be addressed through better policymaking. The CSR UAE Fund runs a CSR SMART PLATFORM to coordinate between the public and private sectors. The platform provides information on the government's development strategy and related projects allowing businesses to contribute to the government's development initiatives. Enterprises can contribute their ideas, time (volunteering), technical, or financial support (Gulf News Report, 2021). The CSR UAE Fund is now working to formulate a tool kit and conduct training sessions to aid small and medium enterprises in taking their plunge into CSR. During the Covid-19 pandemic, the CSR UAE Fund published a comprehensive guide devised by experts to help businesses tailor their CSR strategies and activities to help deal with the global pandemic in line with international best practices and the UAE government's directives. The CSRUAE Fund also worked with a government instituted foundation (Khalifa bin Zayed Al Nahyan Foundation) to provide aid like food, medical equipment, and distance learning equipment for over 395,000 people (WAM,2020).

In addition to government and para-government support for CSR, non-governmental organizations are also involved in aiding businesses with CSR strategy and rewarding enterprises for their CSR. The Dubai Chamber of Commerce has, since 2008, through their Engage Dubai initiative, facilitated the involvement of businesses in their communities and employee volunteer activities. Since 2010 they have been conducting assessments of CSR practices and working with companies to draw up a detailed roadmap for future CSR strategy, and presenting CSR labels to businesses that adhere to international standards of CSR while maintaining local relevance. The Arabic CSR Network is a multistakeholder platform with a database of regional CSR best practices and networking opportunities between regional leaders in CSR with their international peers. Provides practical assistance in implementing CSR strategies, conducts workshops and training activities, and presents Arabia's CSR awards (Arabia CSR Network, 2019). The UAE-based Al Ahli Holding Group has been conducting yearly CSR in Action events to encourage youth involvement. The competition is run over a fourmonth period where participants team up and develop a project to solve the social challenge in local 
communities into a potential social enterprise. (CSR in Action, 2011). Yearly CSR best practices are awarded the Gulf Sustainability, and CSR awards in 12 different streams are awarded to MNCs and SMEs alike (Gulf Sustainability Awards, 2021).

\section{Research Objectives}

1. To understand the key driving factors of CSR of UAE banks.

2. To review the CSR policy and fund implementation in UAE.

3. To examine CSR practices in UAE banking sectors and its implication.

4. To provide policy recommendations on how the banking sector can boost its CSR activities and practices in the UAE.

\subsection{Research Methodology}

During the literature review, it has become evident that there is a distinct lack of academic discussions on CSR in the UAE, even more so in the banking sector. While corporates in the country have slowly picked up CSR practice, academia is yet to take notice. The study is based in the UAE, and it targets the financial sector, more specifically banks. No distinction was made between public, private, or Islamic and non-Islamic banks. The research design of this study is based on the exploratory qualitative research methodology. The nature of exploratory research design explores the research questions, leaving room for further researchers to build on them (Dudovsky, 2012). The study was performed using a two-pronged approach. The first was to examine the driver of CSR in the banking sector, examine the CSR laws and regulations and CSR fund rolled out by the UAE government and its impact. The data for this phase was collected from past published research articles, books, government reports, websites, and social media accounts. The second phase began with the selection of banks to be studied using the purposive sample method. The purposive sampling technique is the deliberate choice of participants due to qualities the participant (organization in this case) possesses. The researcher chose this sampling technique to ensure that all banks selected for the study are currently involved in or in the recent past CSR initiatives. Ten out of the 48 banks in the UAE (national and foreign banks operating in the UAE) were selected using this technique. To examine the impact of CSR initiatives taken by the banks and the CSR UAE Fund, personal interviews were conducted with the CSR UAE Fund management team by using a structured questionnaire. This study's findings will aid academicians interested in studying this topic further and the banking sector to examine their current CSR strategies and build a more refined plan in the future.

\section{Findings}

The research finding shows that all the selected ten banks in the study are currently or in the recent past have executed CSR initiatives. However, the information shared on their website by most banks was fundamental and not extensive. While a time was not set for the study, CSR-related information was collected from banks only if they have indicated being involved in CSR in the period between 2017-2020, on their official website. By analyzing this information, the authors ascertained eleven categories as key areas of interest for CSR in the UAE banking sector. Table 1 data highlights the selected banking sectors' CSR initiatives in different areas and analyses the finding in the discussion.

During the analysis of the website content of CSR in the selected banks, eleven critical areas of interest were ascertained. They are Emiratization, employee development, banks being supportive of people of determination, community development, environmental sustainability, financial literacy, encouraging employees to volunteer, conducting and or sponsoring the cultural event, contributing to social causes or NGOs, conducting health camps, and prioritizing health awareness as well as women empowerment. As indicated in the table below, all the selected banks express an effort to fulfill the affirmative action policy mandated by the Central Bank of UAE to employ nationals (Emirates) in their workforce. Due to this, the banking sector currently employs over $26 \%$ natives and is working on a $40 \%$ 
Emiratization of the sector (Al Rifai, 2019). Community development is a common area of interest with $100 \%$ of the selected banks. CSR projects are undertaken with banks by either forming charitable organizations or contributing to NGOs that work in their communities. The two Islamic banks picked for the study execute 'zakat' while the Emirates Islamic follows donates their zakat funds to social causes; the ADIB collects zakat contributions from customers and directs them to the UAE Zakat Fund'. 70\% of the studied banks concentrate on environmental sustainability as an essential part of their CSR. $60 \%$ of the banks studied engage in employee development by encouraging employees to continue their education, conduction training sessions, and guiding them towards career betterment. 50\% of them encourage their employees to volunteer for social causes. Financial literacy is another significant area of interest, with $50 \%$ of the banks studied setting aside funds and resources to provide the same. Differing from marketing communication, financial literacy educates people about fraudulent practices that lead to consumers losing their money, like scam calls and phishing activities. Cultural events, women's empowerment, and supporting people of determination are the other vital areas. $30 \%$ of the banks extend support to women by helping them come back to work after a break and encourage women to take up leadership positions.

CSR strategy is yet to gain relevance, with most banks undertaking projects in an ad-hoc fashion mostly by commemorating national and international red-letter days. Only $20 \%$ of the study banks have shared their CSR strategy for the following year on their website. However, $40 \%$ of the studied banks have a CSR policy. Reporting and measuring are integral to build a better CSR strategy. However, only $30 \%$ of the banks surveyed have published yearly CSR reports in the last three years (2017-2020). Another $20 \%$ of the banks have included the CSR report as part of their annual report. All three banks which publish separate reports follow internationally accepted yet different reporting practices: due to the lack of a directive from the UAE government of a centralized reporting practice. Emirates NBD and ADIB publish a GRI (Global reporting initiative) compliant yearly CSR report, while the FAB publishes two reports, the ESG (environmental, social, and governance) and Green Bond report. FAB and Emirates NBD also subject themselves to a second party measurement of their CSR activities. Due to the lack of a strategy, it is impossible to ascertain if the CSR activities are aligned with the UN's SDG goals. However, most of the bank's studies state that their goals are aligned with UAE Vision 2021. Additionally, most projects are undertaken in collaboration with government departments like 'Dubai Municipality' and 'Dubai Police'.

Table 1. UAE Banks (Selected for The Study) And the Key Areas of their CSR Strategy

\begin{tabular}{|c|c|c|c|c|c|c|}
\hline BANKS & $\begin{array}{c}\text { Emirat } \\
\text { ization }\end{array}$ & $\begin{array}{c}\text { Employee } \\
\text { development }\end{array}$ & $\begin{array}{c}\text { People of } \\
\text { determination } \\
\text { friendly }\end{array}$ & $\begin{array}{c}\text { Community } \\
\text { Development }\end{array}$ & $\begin{array}{c}\text { Environmental } \\
\text { sustainability }\end{array}$ & $\begin{array}{c}\text { Financial } \\
\text { Literacy }\end{array}$ \\
\hline Mashreq & $\checkmark$ & $\checkmark$ & & $\checkmark$ & $\checkmark$ & $\checkmark$ \\
\hline Bank of Sharjah & $\checkmark$ & $\checkmark$ & $\checkmark$ & $\checkmark$ & $\checkmark$ & $\checkmark$ \\
\hline RAK Bank & $\checkmark$ & & $\checkmark$ & $\checkmark$ & $\checkmark$ & $\checkmark$ \\
\hline ADCB Bank & $\checkmark$ & & & $\checkmark$ & $\checkmark$ & $\checkmark$ \\
\hline $\begin{array}{c}\text { First Abu Dhabi } \\
\text { Bank (FAB) }\end{array}$ & $\checkmark$ & $\checkmark$ & & $\checkmark$ & $\checkmark$ & $\checkmark$ \\
\hline Emirates NBD & $\checkmark$ & $\checkmark$ & $\checkmark$ & $\checkmark$ & & $\checkmark$ \\
\hline Emirates Islamic & $\checkmark$ & & & & & $\checkmark$ \\
\hline CBI Bank & $\checkmark$ & & & $\checkmark$ & $\checkmark$ & $\checkmark$ \\
\hline United Arab & & & & & & $\checkmark$ \\
\hline Bank & $\checkmark$ & $\checkmark$ & & & & $\checkmark$ \\
\hline ADIB & $\checkmark$ & $\checkmark$ & & & & $\checkmark$ \\
\hline
\end{tabular}


Table 1. UAE Banks (Selected for The Study) And the Key Areas of their CSR Strategy (Continue)

\begin{tabular}{|c|c|c|c|c|c|}
\hline BANKS & Volunteering & $\begin{array}{l}\text { Charitable contributions/ } \\
\text { collaboration with NGOs }\end{array}$ & $\begin{array}{l}\text { Cultural } \\
\text { events }\end{array}$ & Health awareness & $\begin{array}{c}\text { Women } \\
\text { Empowerment }\end{array}$ \\
\hline Mashreq & & $\checkmark$ & & $\checkmark$ & \\
\hline $\begin{array}{l}\text { Bank of } \\
\text { Sharjah }\end{array}$ & & & $\checkmark$ & $\checkmark$ & \\
\hline RAK Bank & $\checkmark$ & $\checkmark$ & & $\checkmark$ & $\checkmark$ \\
\hline $\begin{array}{l}\mathrm{ADCB} \\
\text { Bank } \\
\end{array}$ & $\checkmark$ & & $\checkmark$ & & \\
\hline $\begin{array}{c}\text { First Abu } \\
\text { Dhabi } \\
\text { Bank } \\
\text { (FAB) }\end{array}$ & $\checkmark$ & $\checkmark$ & & $\checkmark$ & \\
\hline $\begin{array}{l}\text { Emirates } \\
\text { NBD }\end{array}$ & $\checkmark$ & & & & $\checkmark$ \\
\hline $\begin{array}{l}\text { Emirates } \\
\text { Islamic }\end{array}$ & & $\checkmark$ & & & \\
\hline CBI Bank & & & & & $\checkmark$ \\
\hline $\begin{array}{c}\text { United } \\
\text { Arab Bank }\end{array}$ & & $\checkmark$ & & & \\
\hline ADIB & $\checkmark$ & $\checkmark$ & $\checkmark$ & & \\
\hline
\end{tabular}

Source: Computed by Author from information obtained official websites of the abovementioned banks.

Brand image, government reward systems like the UAE CSR label (for those who have performed CSR and published reports) as well as non-governmental alliances like the Dubai Chamber of Commerce sustainability network, and the urge to give back to the community are the foremost drivers for CSR in the banking sector. $30 \%$ of the banks studied have received awards and other recognitions from national and international organizations involved in measuring the impact of social responsibility projects. For instance, the Mashreq bank even winning the CSR label for nine successive years. Support from the UAE CSR Fund and the government's dedication each year to a cause (2019the year of tolerance) have guided the strategy of the banking sector. It is noted that non-governmental alliances like the sustainability network have contributed immensely to the growth of CSR in this sector before the institution of the UAE CSR Fund in 2018.

The study finding shows that most banks have developed and implemented community-wide CSR initiatives in their area of work. CSR initiatives undertaken by businesses in the banking sector positively impact the overall development of society and businesses. A wide range of CSR initiatives ranging from the nationalization of the workforce, community development, environmental sustainability, and employee development services are developed through these banks. While the focus of CSR projects changed from philanthropic development to sustainable wellbeing, there is very little focus on CSR strategy, banks tend to simply adopt the UAE government's area of focus announced each year. For example, 2019 was observed as the year of tolerance, and 2020 the year of preparing for the next 50 years. While the banks don't directly work towards achieving the SDGs. Their adopting of the country's focus for the year means they are indirectly working towards the SDGs. During the study, it has also been revealed that many banks promote and implement CSR initiatives through the company's human resources department or collaborate with local NGOs; there is a lack of a fully-fledged CSR department. Additionally, only a few banks have a CSR strategy; most undertake CSR activities in an ad-hoc manner.

\section{Conclusion}

CSR has become a salient feature of the corporate strategy of any 21st-century business. In the era of neo-liberal development, governments cannot be expected to do all the work for society and the 
environment. Companies that also benefit from a country's resources must take up their share of the responsibility in securing the country's bright future. Most importantly, the banking sectors can work with governments to mitigate socio-economic inequalities and environmental issues by executing effective CSR projects. The Islamic belief system that promotes philanthropy and the CSR policy of the Government of the UAE has been driving CSR in the banking sector. The banking sector in the UAE has shown initiative in CSR but has not integrated it into its business model. Banks need to align with national CSR targets under the Sustainable Development Goals (SDGs). To achieve its goal of CSR in all companies, the UAE government can begin by encouraging greater reporting of CSR. An annual report on social responsibility must be prepared to highlight the company's commitment to sustainable community development. At present most of the bank follows their reporting model. It would be prudent to provide guidelines regarding the reporting standard to be used; this will help standardize reports making it easy for the CSR UAE Fund to access the work undertaken. There is hardly any disclosure of the budget spent on these activities. Rolling out a mechanism to guide organizations into setting up a budget for CSR spending and mandating transparency in CSR spending will solve this problem. The UAE government can encourage the banking sector of the business world to consider the ethical, social, and environmental issues of the country. The government should play a role in motivating, catalyzing, and facilitating the implementation of CSR in the UAE.

Acknowledgment: We want to thank the University of Dubai for a well-organized conference and other presenters, discussants, and coordinators for their comments and encouragements that helped refine the study. We would also like to extend our thanks to the CSR UAE Fund and the Emirates NBD bank for their inputs.

Author Contributions: Aarthi S.V: writing - original draft (lead), conceptualization (equal), visualization (lead). Mrutuyanjaya Sahu: review and editing (lead), conceptualization (equal), supervision (lead).

Funding: This research received no external funding.

Conflicts of Interest: The authors declare no conflict of interest

\section{References}

A Historical Perspective and emerging theories of CSR. (2018, April 18). The intactone.

A.N. Kostyuk, Ya. I. Mozghovyi, D. A. Riabichenko, D. A. Govorun, \& Yu. H. Lapina. (2013). Corporate Social Responsibility in Banks: An International overview. University of Nairobi

Abdullah, H., \& Valentine, B. (2009). Fundamental and Ethics Theories of Corporate Governance. Middle Eastern Finance and Economics, (4).

ADIB Bank. (2020). Annual Report 2019: ADIB (pp. 43-45).

Akter, N., Bakkar Siddik, A., \& Ali Mondal, S. (2018). Corporate Social Responsibility Disclosure Practices and Banks Financial Performance: A Study on Listed Private Commercial Banks in Bangladesh Building energy and comfort management View project. Journal of Business and Technology (Dhaka), XIII(1).

Al Rifai, N. (2019, October 4). UAE to allocate $40 \%$ of banking jobs to citizens: Central Bank governor. Retrieved May 19, 2021, from www.zawya.com website: https://www.zawya.com/uae/en/economy/story/UAE_to_allocate_40_of_banking_jobs_to_citizens_Centr al_Bank_governor-ZAWYA20191104050321/

Al-Jenaibi, B. (2017). Corporate Social Responsibility: Case Study in UAE Organizations. International Journal of Knowledge Society Research, 8(4), 85-100.

Al-Tamimi, H. A. (2013). Corporate Social Responsibility Practices of UAE Banks. SSRN Electronic Journal, 8(3). https://doi.org/10.2139/ssrn.2312591

Alkubaisy, A. (2020). Corporate Social Responsibility Practice in the Gulf Cooperation Council Countries amidst the COVID-19 Pandemic. Business Ethics and Leadership, 4(4), 99-104. https://doi.org/10.21272/bel.4(4).99104.2020

Almatrooshi, S., Hussain, M., Ajmal, M., \& Tehsin, M. (2018). Role of public policies in promoting CSR: empirical evidence from business and civil society of UAE. Corporate Governance: The International Journal of Business in Society, 18(6), 1107-1123. https://doi.org/10.1108/cg-08-2017-0175

Babiak, K., \& Wolfe, R. (2009). Determinants of Corporate Social Responsibility in Professional Sport: Internal and External Factors. Journal of Sport Management, 23(6), 717-742. https://doi.org/10.1123/jsm.23.6.717 
Balasubramanian, N. K., Kimber, D., \& Siemensma, F. (2005). Emerging Opportunities or Traditions Reinforced? An Analysis of the Attitudes towards CSR, and Trends of Thinking about CSR, in India. The Journal of Corporate Citizenship, (17), 79-92.

Chaudhury, S. K., Das, S. K., \& Sahoo, P. K. (2011). Practices of Corporate Social Responsibility (CSR) in Banking Sector in India: An Assessment. Research Journal of Economics, Business, and ICT, 4, 76-81.

Cheah, E.-T., Jamali, D., Johnson, J. E. V., \& Sung, M.-C. (2011). Drivers of Corporate Social Responsibility Attitudes: The Demography of Socially Responsible Investors. British Journal of Management, 22(2), 305-323. https://doi.org/10.1111/j.1467-8551.2011.00744.x

Companies law set to mandate 2\% CSR spend - India CSR Network. (2011, February 10). Retrieved January 29, 2021, from India CSR Network website: https://indiacsr.in/companies-law-set-to-mandate-2-csr-spend/

Corporate Social Responsibility I UAE. (2020). Retrieved January 27, 2021, from Csruae.ae website: https://www.csruae.ae/en

Cramer, J. (2006). Corporate social responsibility and globalization: an action plan for business. Sheffield: Greenleaf.

CSR in Action. (2011). Retrieved January 29, 2021, from Csralahligroup.com website: https://www.csralahligroup.com/programs/csr-in-action

Dhillon, Dr. J. S. (2013). Ethical Brand Image \& Corporate Goodwill: Issues \& Challenges. International Journal of Management \& Information Technology, 46-53. Retrieved from

Employees Identify “The Green 30" Organizations Based on Eco-Friendly Programs and Practices. (2010, April 22).

Etikan, I., Musa, S. A., \& Alkassim, R. S. (2016). Comparison of Convenience Sampling and Purposive Sampling. American Journal of Theoretical and Applied Statistics, 5(1), 1-4.

Farooq, S., \& Kimani, D. (n.d.). The Relationship between Corporate Governance and Corporate Social Responsibility (CSR) Disclosure: Evidence from the USA. Abasyn Journal of Social Sciences, 8(2).

Franzén, A. A., Wikström, J., \& Nilsson, J. (2010). Internal and external drivers of Corporate Social Performance in developing countries: A case study of Tetra Pak India. Lund University.

Gallego-Sosa, C., Gutiérrez-Fernández, M., Fernández-Torres, Y., \& Nevado-Gil, M. T. (2021). Corporate Social Responsibility in the European Banking Sector: Commitment to the 2030 Agenda and Its Relationship with Gender Diversity. Sustainability, 13(4), 1731. https://doi.org/10.3390/su13041731

Georgiadou, E., \& Nickerson, C. (2020). Exploring strategic CSR communication on UAE banks' corporate websites. Corporate Communications: An International Journal, 25(3), 413-428. https://doi.org/10.1108/ccij-022020-0044

Giannarakis, G., \& Theotokas, I. (2011). The Effect of Financial Crisis in Corporate Social Responsibility Performance. International Journal of Marketing Studies, 3(1). https://doi.org/10.5539/ijms.v3n1p2

Goby, V. P., \& Nickerson, C. (2011). Introducing Ethics and Corporate Social Responsibility at Undergraduate Level in the United Arab Emirates: An Experiential Exercise on Website Communication. Journal of Business Ethics, 107(2), 103-109. https://doi.org/10.1007/s10551-011-1025-4

Gulf News Report. (2021, January 18). UAE to create its index and label for Corporate Social Responsibility initiatives.

Gulf Sustainability Awards 2021. (2021). Retrieved January 29, 2021, from Gulfsustainabilityawards.com website: https://gulfsustainabilityawards.com/

Habisch, A., Jonker, J., Wegner, M., \& Schmidpeter, R. (Eds.). (2005). Corporate social responsibility across Europe. Berlin; New York: Springer.

Hallbäck, V. (2011). Drivers and Barriers for Corporate Social Responsibility in Multinational Corporations: A case study of Wärtsilä, Finland (Master's Dissertation). Linköping University.

Holzinger, M., Ch Zimmerli, W., \& Richter, K. (Eds.). (2010). Corporate ethics and corporate governance. Berlin: Springer.

Hopkins, M. (2009). Evolution of CSR around the Globe - Any Lessons for Canada? Conference Board of Canada.

How Sustainability/ CSR/ ESG/ SDG reporting gives your company a competitive advantage - SustainCase Sustainability Magazine. (2016, September 13). Retrieved from SustainCase - Sustainability Magazine website: https://sustaincase.com/

Iatridis, K. (2011). The Influence of Corporate Social Responsibility on Business Practice: The Case of International Certifiable Management Standard (Ph.D. Thesis). Lancashire Business School.

Islam, Md. T., \& Hamid, Md. K. (2014). The Practice of Corporate Social Responsibility in the Banking Sector of Bangladesh. The Jahangirnagar Journal of Finance and Finance, 2, 25-42. https://doi.org/10.2139/ssrn.2979283

Join Arabia CSR Network - Arabia CSR Network. (2019). Retrieved January 29, 2021, from Arabiacsrnetwork.com website: https://arabiacsrnetwork.com/members/join-arabia-csr-network/

Jones, N. (2017). Next Steps In The Push for Emiratisation In The Financial Sector I Al Tamimi \& Company. 
Khan, Y., \& Szegedi, K. (2020). Corporate Social Responsibility Disclosure in Banking Sector of Pakistan: Evidence from Commercial Banks. Logisztika - Informatika - Menedzsment, 5(1), $24-29$. https://doi.org/10.29177/lim.2020.1.24

Khasharmeh, H. A., \& Desoky, A. M. (2013). Online Corporate Social Responsibility Disclosures: The Case of the Gulf Cooperation Council (GCC) Countries. Global Review of Accounting and Finance, 4(2), 39-64.

KPMG. (2017). Sustainable Development Goals (SDGs): Leveraging CSR to achieve SDGs.

Kuriakose, F. (2017). CSR in India: A Targeted Approach. SSRN Electronic Journal.

Lawrence, S., \& Fernando, S. (2014). A theoretical framework for CSR practices: Integrating Legitimacy theory, Stakeholder Theory, and Institutional theory. Journal of Theoretical Accounting, 149-173.

Lentner, C., Szegedi, K., \& Tatay, T. (2015). Corporate Social Responsibility in the Banking Sector. Public Finance Quarterly.

Martínez, P., \& Bosque, I. R. del. (2013). CSR and customer loyalty: The roles of trust, customer identification with the company, and satisfaction. International Journal of Hospitality Management, 89-99.

Martins, A. (2019, June 4). Most Consumers Want Sustainable Products and Packaging.

Masoud, N. (2017). How to win the battle of ideas in corporate social responsibility: the International Pyramid Model of CSR. International Journal of Corporate Social Responsibility, 2(1). https://doi.org/10.1186/s40991-0170015-y

N. K. Gupta, \& Kasana, J. (2017). An Empirical Study on the Effect of Business Ethics on the Company's CSR Practices. International Journal of Business Management $\mathcal{E}$ Research, 7(6), 21-34. https://doi.org/10.24247/ijbmrdec20173

Neelmani Jaysawal, \& Sudeshna Saha. (2015). Corporate Social Responsibility (CSR) in India: A Review. Space and Culture India, 3, 81-93.

Noeiaghaei, N. (2009). Corporate Social Responsibility in UAE: A Case Study of Jumeirah Group's CSR Practices (Master's Dissertation).

Okur, H. (2015). Corporate Social Responsibility and Sustainability in the United Arab Emirates (Master's Dissertation). FAU.

Omran, M. A., \& Ramdhony, D. (2015). Theoretical Perspectives on Corporate Social Responsibility Disclosure: A Critical Review. International Journal of Accounting and Financial Reporting, 5(2), 38. https://doi.org/10.5296/ijafr.v5i2.8035

Pal, A. (2016, October). Consumers as Drivers of CSR.

Pinnington, A. H. (2013). Corporate Social Responsibility ( CSR ) in the United Arab Emirates (Master's Dissertation). The British University in Dubai.

Pradip Kumar Sahu. (2013). Research Methodology: A Guide for Researchers In Agricultural Science, Social Science, and Other Related Fields. India Springer India.

Pyszka, A., \& Gajda, D. (2015). Successful talent management through positive CSR- driven transactions. Journal of Positive Management, 3-19.

Rahman, A. A., \& Bukair, A. A. (2013). View of The Influence of the Shariah Supervision Board on Corporate Social Responsibility Disclosure by Islamic Banks of Gulf Co-operation Council Countries. Asian Journal of Business and Accounting, (ISSN 1985-4064). Retrieved from https://ajba.um.edu.my/article/view/2678/877

Rahman, M., Ahsan, A., Hoq, M. R., \& Shah, M.-U.-A. (2013). CSR Practices in Private Sector Banking in Bangladesh: A Case Study on National Bank Limited. Asian Accounting and Auditing Advancement, 3(6), 814.

Rahul, R. (2012a, July 16). Theories of CSR. Retrieved January 30, 2021, from Project Guru website: https://www.projectguru.in/theories-of-csr/

Rahul, R. (2012b, August 10). Evolution of corporate social responsibility. Retrieved May 19, 2021, from Project Guru website: https://www.projectguru.in/evolution-of-corporate-social-responsibility/

Robé, J.-P. (2012). Being Done With Milton Friedman. Accounting, Economics, and Law, 2(2). https://doi.org/10.1515/2152-2820.1047

SAFWAT, A. M. (2015). Corporate Social Responsibility: Rewriting the Relationship between Business and Society. International Journal of Social Sciences, IV(1), 87-99. https://doi.org/10.20472/ss2015.4.1.006

Sajadi Far, V. (2013). Corporate Social Responsibility (CSR) in the United Arab Emirates (Master's Dissertation). The British University of Dubai.

Schönherr, N., Findler, F., \& Martinuzzi, A. (2017). Exploring the interface of CSR and the Sustainable Development Goals. Transnational Corporations, 24(3), 33-47. https://doi.org/10.18356/cfb5b8b6-en

Singh, S., Bawa, J., \& Sharma, G. D. (2016). A case study on Corporate Social Responsibility in NESTLE, TATA, ITC. ADR Journals. 
Singh, S., \& Kukunuru, S. (2017). Corporate Social Responsibility and Impact on Profitability of Banks in the United Arab Emirates. Middle East Journal of Business, 12(1), 12-22. https://doi.org/10.5742/mejb.2017.92903

Smith, B., Reeves, J., \& Boden, S. (2018a, May). CSR Law In The UAE: Are You Ready? - Corporate/Commercial Law - United Arab Emirates. Retrieved May 19, 2021, from www.mondaq.com website: https://www.mondaq.com/corporate-and-company-law/699592/csr-law-in-the-uae-are-you-ready

Smith, B., Reeves, J., \& Boden, S. (2018b, May 7). CSR Law in the UAE: Are you ready? Retrieved from Lexology.com website: https://www.lexology.com

Soukaina Rachidi. (2017, March 16). Improving the art of CSR in the UAE's Year of Giving. Retrieved January 27, 2021, from ArabianBusiness.com website.

Tariq Khan, Dr. M., Ahmed Khan, Dr. N., Ahmed, S., \& Ali, M. (2012). Corporate Social Responsibility (CSR)Definition, Concepts, and Scope (A Review). Universal Journal of Management and Social Sciences, 2(7).

Toal, B., \& Broomes, V. (2021). The drivers for CSR. Retrieved from Alchemyformanagers.co.uk website: https://www.alchemyformanagers.co.uk/

Vinerean, S., Cetina, I., \& Dumitrescu, L. (2013). Modeling Employee Satisfaction in Relation to CSR Practices and Attraction and Retention of Top Talent.

Visser, W. (2008, August 3). CSR Drivers. Retrieved from Waynevisser.com website: http://www.waynevisser.com/articles/csr-drivers

Visser, W., Matten, D., Pohl, M., \& Tolhurst, N. (2008). The A to Z of corporate social responsibility: a complete reference guide to concepts, codes, and organizations. : Institute for Corporate Cultural Affairs.

Waheed Abbas. (2020). Coronavirus in UAE: Dubai banks roll out major relief measures for residents.

Whelan, T., \& Kronthal-Sacco, R. (2019, June 19). Research: Actually, Consumers Do Buy Sustainable Products.

(C) 2020 by the authors. This article is an open-access article distributed under the terms and conditions of the Creative Commons Attribution (CC BY) license (http://creativecommons.org/licenses/by/4.0/). 